\title{
Governance Structure and Related Party Loan Guarantees: The Gase of Ghinese Family Business Groups
}

\author{
Xin Chen, ${ }^{1}$ Jakob Arnoldi, ${ }^{2}$ and Chaohong $\mathbf{N a}^{3}$ \\ ${ }^{1}$ Shanghai fiao Tong University, China, ${ }^{2}$ Aarhus University, Denmark, and ${ }^{3}$ Yunnan University of \\ Finance and Economics, China
}

ABSTRACT Loan guarantees to related parties by affiliated subsidiaries within family controlled pyramids form a means by which the controlling family expropriates value from minority shareholders. The controlling family, however, will attempt to escape blame for the behavior. Using a sample of 1785 listed Chinese firms affiliated with family-controlled business groups, we explore how family governance structure affects the use of related party loan guarantees. As hypothesized, we find that affiliates with non-family chairmen, but with family directors or senior executives, issue larger volumes of loan guarantees to related parties, whereas affiliates with family chairmen and those with non-family interlocking chairmen do not. The behavior is moderated by regional institutional development.

KEYworDS China, expropriation, family business groups, loan guarantees

\section{INTRODUCTION}

In spite of being publicly listed on stock markets, many large public companies in China continue to be controlled by other firms through affiliation with a pyramidal business group. In many cases, the controlling apex firms of such pyramids are family owned. As is the case for family-owned firms generally (Chrisman, Chua, Pearson, \& Barnett, 2012; Lubatkin, Ling, \& Schulze, 2007; Luo \& Chung, 2005), a family owner of a pyramidal business group may place family members as managers or directors in affiliated firms, including the listed one(s) (Chung \& Chan, 2012). By creating such a family tie between the controlling (apex) and the listed affiliated firm, the family owners may (seek to) boost their control over the listed affiliated firms. According to agency theory, such family involvement increases family control over a firm, which in turn may increase principal-principal (P-P) problems, for example in

Corresponding author: Chaohong Na (chna@ynufe.edu.cn) 
the form of expropriation of minority shareholders (Bhaumik \& Gregoriou, 2010; Sharma \& Chua, 2013; Young, Peng, Ahlstrom, Bruton, \& Jiang, 2008).

In this study, we are not concerned with analyzing why family-owned or managed firms may expropriate minority shareholders and not with investigating what motivates some family owners to expropriate and some not to. Instead, we investigate how family owners use specific control structures to facilitate expropriation or how specific pre-existing control structures either ease expropriation or constrain such attempts. Specifically, we analyse how three specific types of control structures using family involvement in the affiliated subsidiaries of family controlled groups: a) family chairman; b) non-family chairman but with family director(s) or manager(s); and c) non-family chairman interlocked with the family group's apex firm are associated with the use of affiliates' loan guarantees to related parties, a form of expropriation of the non-family owners of the affiliates.

We find evidence that family presence, in the form of having a non-family chairmen but with family board members or senior executives increases the amount of loan guarantees made by listed affiliates $(\mathrm{LAFs})$ to related parties within the family controlled groups. However, this is not the case when an LAF's chairman is a family member or a non-family member interlocked with the apex firm. In fact, non-family interlocking chairmen are found to have the opposite effect in that they reduce the volume of related-party loan guarantees. Furthermore, regional institutional development is shown to moderate the effect of family presence on loan guarantees.

We contribute to our understanding of family-owned businesses generally and those in China specifically. As to the former, family business researchers have to an increasing degree differentiated between different structures of family ownership and management (Chua, Chrisman, Steier, \& Rau, 2012). Our primary contribution in this regard consists of showing how different managerial structures, including different forms of family involvement, are associated with differences in the expropriation of non-family owners.

As for research on China's family ownership, our juxtaposition of two types of ties, family and non-family vertical interlocks, provides unique insights into two important control mechanisms in China's family-owned business groups. From an organizational design perspective, interlocking ties are structurally and functionally comparable with family ties; both are managerial ties between affiliated and apex firm and both can be expected to increase apex firm control over the affiliated firm. However, our results show vast differences between these two types of ties in relation to how they are used in China to expropriate non-family owners.

Finally, our study provides insight into the effect of institutional development, which is an important question for family-owned business scholarship (Gedajlovic, Carney, Chrisman, \& Kellermanns, 2012; Jiang \& Peng, 2011; Peng \& Jiang, 2010; Young et al., 2008). While most studies of institutional development compare different countries, our study shows that institutional differences within a country, 
in this case across China's regions, can create significant heterogeneity in family firm behaviour within one country.

\section{THEORETICAL BACKGROUND AND HYPOTHESES}

Agency theory has to an increasing degree focused on conflicts between majority and minority owners (Young et al., 2008). Concentration of control creates incentives for the majority owner to extract value from the firm at the cost of minority owners. Such expropriation of minority owners (or 'tunnelling') may take different forms, for example through transactions with - or loans or loan guarantees to - another firm owned by the majority shareholder (Bhaumik \& Gregoriou, 2010; Cheung, Rau, \& Stouraitis, 2006; Claessens, Djankov, \& Lang, 2000; Khanna \& Yafeh, 2007; La Porta, Lopez-de-Silanes, \& Shleifer, 1999; Masulis, Pham, \& Zein, 2011). Also pyramidal structures are associated with principal-principal (P-P) agency problems (Liu, Zheng, \& Zhu, 2010). Generally, pyramidal groups are formed as a way of mitigating transaction costs and financial constraints due to institutional voids (Carney, Gedajlovic, Heugens, Essen, \& Oosterhout, 2011; Khanna \& Yafeh, 2005; Masulis et al., 2011; Miller, Lee, Chang, \& Le BretonMiller, 2009). This also seems to apply to Chinese pyramids (He et al., 2013; Keister, 1998). But ownership of controlling but not full stakes in firms, especially controlling but not full ownership stakes in the succeeding pyramidal tiers, creates divergence between cash flow and voting rights, granting the majority owner control rights disproportional to the cash flow rights. This further stimulates the majority owner's incentive to expropriate (Bhaumik \& Gregoriou, 2010).

Using loan guarantees to ensure credit to other firms under family ownership is one (important) way of expropriating minority shareholders (Berkman, Cole, \& $\mathrm{Fu}, 2009$ ). While loan guarantees to related parties can be viewed simply as a way of mitigating intra-group financial constraints, they obviously hurt the affiliated firms or subsidiaries (affiliates) as their ability to finance at low costs is hampered or clearing loans in the case of loan default lays a burden on them. An alternative measure of expropriation activities is constituted by inter-corporate loans provided to related parties. However, due to government regulation, controlling shareholders of Chinese listed firms repatriated most of their remaining loan balances by the end of 2006 (Jiang, Lee, \& Yue, 2010) and have largely stopped using such loans as a method of expropriation since then. This, we argue, has increased the importance of loan guarentees. Moreover, compared to noisy related party transactions, for which the direction of expropriation may be ambiguous, loan guarantee is a better measure of expropriation since the benefit flow is clear. For example, Berkman et al. (2009) find that Tobin's Q, ROA, and Chinese firms' dividend yields are negatively affected by loan guarantees issued to their related parties while Jiang, Lee, and Yue (2010) report that companies with large loan balances to related parties exhibit poorer future operating performance and earn lower risk-adjusted returns in the subsequent year. 
The body of literature published in international journals investigating family ownership in China is relatively small (Kim \& Gao, 2010). Cai, Luo, and Wan (2012) find that family CEOs enhance performance as does concentrated family ownership. Luo and Chung (2013) find that more direct strategic control (obtained through having a family member serve as the board chairman) creates a bigger positive performance effect than mere family ownership. At the same time, having a non-family general manager adds further value to family-owned firms. The reason, Luo and Chung (2013) argue, is that independent general managers reduce the risk of the family owners expropriating minority shareholders. Family ownership and strategic control combined with an independent executive further increase performance when the level of institutional development is low. Zhou, Tam, and $\mathrm{Yu}$ (2013) find that direct family leadership benefits performance but also find that family owners' additional control measures are detrimental to performance. Contradicting these findings slightly, Kim and Gao (2010) find no performance effect of family management but they do find a positive effect of having family managers with strategic interest in family longevity and financial stability. Thus, research has shown that family ownership can take different shapes, in turn creating varying degrees of control (Chung \& Chan, 2012) with varying performance outcomes (Luo \& Chung, 2013).

The issues mentioned so far are related to family ownership, not necessarily family involvement, and it has indeed been debated whether the underlying cause of the P-P problems just mentioned is concentration of ownership rather than family ownership itself (Chrisman et al., 2005; Singal \& Singal, 2011). ${ }^{[1]}$ Most family-owned firms exhibit family involvement beyond ownership. Such involvement may come about through the appointment of family managers or directors (Sirmon, Arregle, Hitt, \& Webb, 2008). Without necessarily dwelling on why or how, agency theory generally assumes that family involvement at least potentially increases P-P agency problems because family managers or directors owe more loyalty to, and have more interest in, the family (and the group of firms under family ownership generally) than the specific firm under their leadership (Lubatkin, Schulze, Ling, \& Dino, 2005; Lubatkin et al., 2007). Thus, family managers or directors may act in the family's (private) interest rather than in the interest of the firm (Gedajlovic et al., 2012: 1014). Similar to transaction cost economics and social network theory, agency theory holds family ties to create loyalty, trust, and information exchange, reducing costs of contract enforcement (Fama \& Jensen, 1983) and principal-agent (P-A) agency problems (Chung \& Chan, 2012), but adding to potential conflicts with minority owners who may be marginalized in terms of influence and access to information.

Based on the above argument, we see family ties fundamentally as channels of control and coordination. Therefore, appointing a family manager or director of an LAF creates a tie between the listed affiliated and apex firm, which increases the family control over the LAF. For example, the family owner will be able to command more loyalty and have better access to information. Still, this does not mean that 
such control always leads to an increase in P-P problems. Family owners may have different motives for creating such control structures and use them differently (Le Breton-Miller \& Miller, 2009). Yet, when a family owner intends to expropriate, a family manager's or director's loyalty may make that easier.

The control effect of a family tie is not necessarily only a function of the degree of loyalty, trust, and information exchange, which family ties create. The control effect may also hinge on the degree of managerial leverage possessed by the appointed family manager or director. That is, the higher the managerial position, the more control the family will gain. This is similar to social ties generally, where the value of Ego having a tie to Alter is higher the greater Alter's resources (wealth, power, reputation, etc.) (Bourdieu, 1986). As a result we may expect a family member with the highest degree of leverage in the LAF to afford the family the greatest control. In China, compared to most other countries, board chairmen have more executive responsibilities as well as legal responsibilities and liabilities (Liao, Chen, Jing, \& Sun, 2009). The highest possible degree of leverage thus lies with the chairman of the board. Hence, we arrive at our first hypothesis:

Hypothesis 1: The volume of loan guarantees to related parties by a listed firm affiliated with a family-owned business group will be positively related with the listed affiliate having a chairman from the controlling family.

Another common type of family involvement is to appoint relatives as board member(s) but not as board chairman of the LAF. There are several reasons why this form of family involvement may increase the likelihood of using LAFs for relatedparty loan guarantees. Following the theoretical reasoning above, family owners may prefer having family members present in a listed firm in less conspicuous roles than chairman if they intend to issue loan guarantees to related parties. Or alternatively, less visible family presence may offer means to issue loan guarantees that become an incentive for the family owners balancing the power wielded and visibility and liability. For example, Chinese board chairs are personally and quite transparently legally liable and in many other ways they are the visible profiles of the listed firms. Thus, appointing family as board members or senior managers may, even though such positions afford less formal managerial power over the listed firm, be in the interest of the family because it can 'conceal' its involvement. Compared to board chairs, family directors in China operate under fewer regulatory constraints. Moreover, while these positions yield less formal power, family membership may nevertheless grant them significant informal power in the firm, which can be used to ensure that a listed firm issues related party loan guarantees. Thus, the formal power of the board chairmanship may be redundant and the increased visibility would not be desirable for the family. Based on this, we formulate the following hypothesis:

Hypothesis 2: The volume of loan guarantees to related parties by a listed firm affiliated with a family-owned business group will be positively related with the listed affiliate having a 
non-family chairman $A \mathcal{N D}$ at least one board member or senior executive from the controlling family.

We have conceptualized family involvement as family ties between the apex and listed affiliated firms. This raises questions about other comparable ties. Many executives or directors of LAFs, including non-family members, also hold managerial positions in the apex firms thus forming vertical interlocks. For example, a non-family member is board chair of an LAF while at the same time holding a position of president in the apex firm. Such non-family vertical interlocks are directly comparable to family ties for two reasons: Firstly, interlocks are managerial ties between affiliated and apex firms (Khanna \& Thomas, 2009: 183). Secondly, interlocks are channels of coordination and control (Haunschild \& Beckman, 1998; Rocha, 2012). Research suggests that the dominant firm appoints one of its managers or directors as board member of the dominated firm in order to monitor and control it (Lincoln, Gerlach, \& Takahashi, 1992). Applying this to family-owned business groups, vertical interlocks would be levers of control for the family-owned apex firms similar to family ties (as described in $\mathrm{H} 1$ and $\mathrm{H} 2$ ). As a result, P-A agency problems would be reduced but with a corresponding increase in P-P problems. It cannot be expected that any LAF managers other than chairs would be offered interlocking positions in the apex firm as having a lower ranked executive with direct access to the apex firm would undermine the chair. Based on this, we formulate the following hypothesis:

Hypothesis 3a: The volume of loan guarantees to related parties by a listed firm affiliated with a family-owned business group will be positively related with the listed affliate having a non-family chairman with interlocking ties to the apex firm.

While interlocks indeed are important levers of control, the direction of the flow of control is less certain. Having an interlocking position may give a LAF top manager more influence on decisions made by the apex firm. Using that influence, the LAF firm manager may be able to block the apex firm's attempt to expropriate the LAF by means of loan guarantees or to reduce the extent of loan guarantees. Moreover, having such an interlocking position may afford a non-family chair of an LAF with enough leverage to counter the family control due to family executives or directors in the LAF. Non-family chairmen may actively work against such use of loan guarantees because it harms the listed firm's performance and thus indirectly their own professional track record. Mention should also be made of the fact that interlocking chairmen often draw the main part of their salary from the LAF and not the apex firm, which may indeed guide their loyalty. Last but not least, the interlocks may also be so visible to minority shareholders and other stakeholders, and held to be levers of influence for the family, that the family owners shy away from using loan guarantees in situations where interlocks exist in order to escape blame for expropriation. Thus, following the logic also behind H2, a too obvious 
family control mechanism, an interlock, could potentially keep family owners from using loan guarantees. Hence, we formulate a competing hypothesis:

Hypothesis 3b: The volume of loan guarantees to related parties by a listed firm affiliated with a family-owned business group will be negatively related with the listed affiliate having a non-family chairman with interlocking ties to the apex firm.

Institutional development affords minority shareholders protection and can generally be assumed to reduce P-P problems because it entails increased transparency and enforced regulation (Peng, 2004; Xu, Zhu, \& Lin, 2005). China exhibits substantial cross-regional variance of institutional development. We expect this variance to moderate the P-P problem and thus the effect both of family involvement (Chakrabarty, 2009; Peng \& Jiang, 2010) and non-family interlocks. Symmetrically, any incentive to use an LAF to extend loan guarantee is further enhanced under conditions of loose regulation. Based on this we can formulate two hypotheses for the moderating effects of institutional development:

Hypothesis 4: The positive association between volume of loan guarantees to related parties by a listed firm affiliated with a family-owned business group and the affiliate having a non-family chairman along with family presence will be negatively moderated by institutional development.

Hypothesis 5: The association between volume of loan guarantees to related parties by a listed firm affiliated with a family-owned business group and the affiliate having an interlocked non-family chairman will be negatively moderated by institutional development.

\section{METHOD}

\section{Data and Sample Selection}

We obtained data on loan guarantees to related parties, governance and financial reports from the Wind database, which is the most popular commercial provider of financial datasets on listed firms in China. Additional governance data was obtained from the CCER database, developed by the China Center for Economic Research and Sinofin Corporation. Data on vertical interlocks and on managers' family background was collected from background descriptions of executives in annual reports and through Internet searches. Further information about the control chain of business groups was obtained from annual reports. Chinese listed firms went through a 'Non-tradable share reform' in 2005 and 2006, which transformed nontradable controlling blocks into tradable shares. The reform reshaped controlling shareholders' expropriation incentives. Our sample period therefore starts from 2007 to evade the influence of the reform and ends in 2010. Firms included in our sample are listed on the Shanghai Stock Exchange, the main board of the Shenzhen Stock Exchange or the Shenzhen SME Board. We excluded financial firms completely and the data for the IPO years of sample firms that went public within the sample period. 
We started out with 2369 firm-year observations of privately controlled listed firms in the period 2007 to 2010 . Nine firms in the bank and finance industry were struck from the sample and we further eliminated 392 observations of firms directly controlled by individuals or foreign firms/institutions as well as firms without individual ultimate controllers, since the vertical interlocks we examine require each listed firm to be affiliated with a family-controlled business group. Lastly, 133 observations in their IPO years were excluded (the 'Growth Enterprise Market' has many family firms, but these firms are excluded from our analysis since the board was established in 2010) as well as 50 observations with missing data. The final sample consists of 1785 year-firm observations thus comprising approximately 446 firms per year.

\section{Variables}

In our sample the control of all listed firms can be traced to individuals or their families. Controlling shareholders very often place family members (including themselves) in the LAF. Family is defined as siblings, children, and parents of the individual or marital couple that are the ultimate controllers (including spouses). We obtained information on family relatives from annual reports supplemented by information obtained from Baidu and Google.

First, we define FAMILYCHAIR as a dummy variable indicating whether the chairman of a listed firm affiliated with a family business group belongs to the family of the LAF's ultimate controller. NFG (Non-family chair) is a dummy set at 1 if a LAF chairman is not related to the controlling family. Naturally, NFC is equal to 1-FAMILYCHAIR. In addition, we define FAMINV (family involvement) as a dummy variable indicating that family members of the ultimate controllers are appointed as directors (including chairman), supervisors, or senior managers of LAFs. Consequently, family presence in combination with NFG, where involvement is in the form of family directors (other than chairman), supervisors, or senior managers, can be captured by NFG*FAMINV.

A vertical interlock exists when a chairmen of the board of an LAF at the same time holds senior managerial or board positions in the controlling apex firm. As discussed previously, it is reasonable to use chairman of the board as the representative of the LAF because the China's chairmen of the board have more executive responsibilities as well as legal responsibilities and liabilities (Liao, Chen, Jing, \& Sun, 2009). We define INTERLOCK as 0 if a chairman of an LAF has no interlocking position in the apex firm; 1 if a chairman holds a position at the divisional manager level or higher in the apex firm. We measure related party loan guarantee (RPLG) as the loan guarantees provided to related parties divided by the total assets of LAFs. We define related parties as the ultimate controller of the listed firm (the family business group) or its affiliates. The level of institutional development is used as both a control variable and a moderating variable. We use MINDEX, the National Economic Research Institute's (NERI) 
marketization index as a measure of the institutional development of the province in which the listed affiliated firms is headquartered. Although the intent and decision to expropriate stems from the apex firm, which may be located in a different province, the guarantor is the listed affiliated firm. For that reason, it is the institutional framework of the listed affiliated firm's province - and not that of the apex firm - that to the largest degree constrains (or facilitates) such expropriation.

Control variables. Divergence is a measure of divergence between the voting rights and cash flow rights of the ultimate controller, defined as the largest percentage shareholdings minus the percentage of cash flow rights owned by the ultimate controller. Higher divergence normally indicates stronger incentives to expropriate minority shareholders suggesting positive effects on RPLG. Layer is the number of intermediate layers between the ultimate controllers and the LAFs; it can proxy the complexity of a business group. LAFs with more layers can have a greater volume of loan guarantees to related parties since complex groups may have a higher demand for loan guarantees. LNASSETS is the natural logarithm of total assets as a measure of firm size. Leverage is the financial leverage of an LAF, calculated as the ratio of total liabilities to total assets. It is not clear how leverage affects loan guarantees. We assume however, that highly leveraged firms may be less capable of carrying additional financial burdens such as providing loan guarantees. However, leverage may also be a sign that the controlling family generally sees the listed affiliated firm as a vehicle for financial support of other firms, in which case high leverage could be associated with high volume of loan guarantees. Empirical testing will determine whether any of these explanations hold true.

ROE is the measure of firm profitability defined as the ratio of net income to book value of equity. Growthsales is the growth rate of sales. A controlling family may expropriate firms with high growth opportunities to a lesser extent given that promising firms are liable to create great value in the future. Topshare is the percentage of the LAF's shares held by the largest shareholder. Higher Topshare means greater percentage profit that the controlling families can share, which may lead them to expropriate LAFs less. Firmage is a proxy of maturity measured by the number of years since IPO of LAFs. CEOduality is a dummy variable measuring whether one person holds positions as chairman as well as general manager in the LAF. Boardsize is the total number of directors on the LAF board. The number of directors is particularly important since Chinese regulations require that the board of directors or the shareholders' assembly approve external loan guarantees. It is suggested that the larger the number of directors (assuming that they are not all family members), the greater the difficulty for the controlling family to use loan guarantees. Thus, we assume Boardsize to be negatively associated with RPLG. Due to the extreme observations, we winsorize RPLG, ROE and Leverage at $1 \%$ and $99 \%$ to avoid bias due to outliers. 
Table 1. Sample structure by family involvement and vertical interlock

\begin{tabular}{|c|c|c|c|c|}
\hline \multirow[b]{2}{*}{$\begin{array}{l}\text { Vertical } \\
\text { Interlock }\end{array}$} & \multirow[b]{2}{*}{$\begin{array}{c}\text { Family Chair } \\
\text { Family Involvement }\end{array}$} & \multicolumn{2}{|c|}{ Non-family Chair } & \multirow[b]{2}{*}{ Total } \\
\hline & & $\begin{array}{l}\text { Family Involvement } \\
\text { (Family Presence) }\end{array}$ & $\begin{array}{l}\text { Non-Family } \\
\text { Involvement }\end{array}$ & \\
\hline 0 & 4 & 252 & 294 & 550 \\
\hline 1 & 814 & 196 & 225 & 1,235 \\
\hline Total & 818 & 448 & 519 & 1,785 \\
\hline
\end{tabular}

\section{Testing Hypotheses}

We use OLS models to test our hypotheses; the hierarchical results are presented in Table 3. We use one-year lagged values for all independent variables to avoid simultaneity. Model 1 includes only the control variables. Model 2 tests $\mathrm{H} 1$ and H2 simultaneously by the coefficients for FAMILYCHAIR and NFG*FAMINV. Since NFG*FAMINV and NFG*INTERLOCK are highly correlated, we did not include the variables in the same model. Therefore, $\mathrm{H} 3$ is tested by Model 3 using the coefficients of NFG*INTERLOCK. Note that there is no need to test the direct effect of NFG because, as discussed previously, NFG $=1$-FAMILYCHAIR. Lastly, we test $\mathrm{H} 4$ and $\mathrm{H} 5$ with Models 4 and 5 in Table 3 by the coefficients for NFG*FAMINV*MINDEX and NFG*INTERLOCK*MINDEX, respectively.

\section{RESULTS}

\section{Sample Structure of Family Involvement and Vertical Interlock}

As seen in Table 1, of the total 1785 firm-year observations, 818 LAFs have family chairman. Most of these family chairmen also hold a position in the apex firm (814 out of 818) thus creating an interlock. The rest - 967 observations - have non-family chairman, among which 448 also have family presence as directors or other senior managers in LAFs (252 without vertical interlock and 196 with vertical interlock) and 519 have no family involvement at all (194 without vertical interlock and 225 with vertical interlock).

\section{Descriptive Statistics}

Table 2 shows that in our sample a typical LAF has $9.61 \%$ of divergence between control rights and cash flow rights, a pyramidal control chain of three layers, natural log of total assets of 21.05, financial leverage of 50.4\%, 7.41\% ROE, $12.5 \%$ growth rate of sales, largest share holdings of $29.4 \%$, firm age of 10.13 years, and a board size of 9 . Besides, $69.2 \%$ of LAF chairmen hold interlocking positions in the apex firms, $70.9 \%$ of the LAFs have members of controlling families appointed as director, supervisor or senior management, and $22.1 \%$ of chairmen also hold the 
Table 2. Summary statistics

\begin{tabular}{lcccccc}
\hline \hline Variables & $\mathcal{N}$ & Max & Median & Mean & Min & Std \\
\hline RPLG & 1785 & 1.167 & 0 & 0.0322 & 0 & 0.139 \\
INTERLOCK & 1785 & 1 & 1 & 0.692 & 0 & 0.462 \\
FAMINV & 1785 & 1 & 1 & 0.709 & 0 & 0.454 \\
NFG & 1785 & 1 & 1 & 0.542 & 0 & 0.498 \\
FAMILYCHAIR & 1785 & 1 & 0 & 0.458 & 0 & 0.498 \\
DIVERGENGE & 1785 & 0.445 & 0.0961 & 0.109 & 0 & 0.0835 \\
LAYER & 1785 & 10 & 3 & 3.625 & 3 & 0.984 \\
MINDEX & 1785 & 11.8 & 9.02 & 8.949 & 0.38 & 2.213 \\
LANASSETS & 1785 & 24.6 & 21.05 & 21.01 & 11.35 & 1.241 \\
LEVERAGE & 1785 & 10.43 & 0.504 & 0.711 & 0.0626 & 1.218 \\
ROE & 1785 & 0.766 & 0.0741 & 0.0808 & -0.766 & 0.178 \\
GROWTHSALES & 1785 & 12.97 & 0.125 & 0.359 & -0.978 & 1.496 \\
TOPSHARE & 1785 & 0.852 & 0.294 & 0.322 & 0.0249 & 0.146 \\
FIRMAGE & 1785 & 20.07 & 10.13 & 9.58 & 1.016 & 4.672 \\
CEODUALITY & 1785 & 1 & 0 & 0.221 & 0 & 0.415 \\
BOARDSIZE & 1785 & 15 & 9 & 8.626 & 3 & 1.667 \\
\hline \hline
\end{tabular}

Notes: RPLG is the amount of loan guarantees provided to related parties scaled by total assets; INTERLOCK is equal to 1 if the affiliated chairman has an interlocking position at the apex firm, and otherwise 0; FAMINV is equal to 1 if the controlling family of a listed firm has appointed at least one family member at the listed firm as director (including chairman), supervisor or senior manager and otherwise 0; NFG (Non-family chair) is a dummy set at 1 if a LAF chairman is not related to the controlling family; FAMILYCHAIR is a dummy variable indicating whether the chairman of a listed firm affiliated with a family business group belongs to the family of the LAF's ultimate controller; DIVERGENCE is defined as the largest shareholding in percent minus the percent of cash flow rights owned by the controlling family; LAYER is the number of intermediate layers between the ultimate controller and listed firms; MINDEX is the NERI Index of Marketization for China's provinces where the headquarters of listed firms are located; LNASSETS means natural log of total assets of listed firms; LEVERAGE is calculated as the ratio of total liabilities to total assets; ROE is defined as the ratio of net income to book value of equity; GROWTHSALES is the growth rate of sales; TOPSHARE is the percentage of shares held by the largest shareholder; FIRMAGE is the number of years since the IPO of the listed firm; CEODUALITY is a dummy variable measuring whether the same person is holding both positions of chairman and general manager; BOARDSIZE is the total number of directors on the board.

position of general manager in LAFs. Finally, the average loan guarantee to related parties in our sample is $3.22 \%$ of total assets.

\section{Regression Results}

Table 3 shows the OLS regression results. The dependent variable is RPLG. Model 1 is the baseline model not including variables of family governance. From Model 2, we start to include family governance variables. The coefficient for FAMILYCHAIR in Model 2 is 0.007 but not significant. The results indicate that whether the chairman of the LAF is a family member or not has no effect, in itself, on RPLG. Thus $\mathrm{H} 1$ is not supported. The coefficient for NFG*FAMINV, also in Model 2, is 0.018 ( $\mathrm{p}<0.05$ ) indicating support for $\mathrm{H} 2$ while the coefficient for NFG*INTERLOCK in Model 3 is -0.024 ( $p<0.01$ ) indicating support for H3b.

The economic importance of the effect of family governance is large. The results indicate that after controlling for other factors, a non-family chairman with family 
Table 3. OLS regression results

\begin{tabular}{|c|c|c|c|c|c|}
\hline Dependent $=R P L G$ & (1) & (2) & (3) & (4) & (5) \\
\hline DIVERGENGE & $\begin{array}{l}0.129^{* * *} \\
(2.98)\end{array}$ & $\begin{array}{l}0.128^{* * *} \\
(2.96)\end{array}$ & $\begin{array}{l}0.134^{* * *} \\
(3.10)\end{array}$ & $\begin{array}{l}0.111^{* *} \\
(2.56)\end{array}$ & $\begin{array}{l}0.135^{* * *} \\
(3.11)\end{array}$ \\
\hline LAYER & $\begin{array}{l}-0.002 \\
(-0.54)\end{array}$ & $\begin{array}{l}-0.001 \\
(-0.30)\end{array}$ & $\begin{array}{l}-0.001 \\
(-0.22)\end{array}$ & $\begin{array}{l}-0.000 \\
(-0.09)\end{array}$ & $\begin{array}{l}-0.001 \\
(-0.20)\end{array}$ \\
\hline LNASSETS & $\begin{array}{l}-0.004 \\
(-1.24)\end{array}$ & $\begin{array}{l}-0.005 \\
(-1.44)\end{array}$ & $\begin{array}{l}-0.004 \\
(-1.13)\end{array}$ & $\begin{array}{l}-0.004 \\
(-1.32)\end{array}$ & $\begin{array}{l}-0.004 \\
(-1.13)\end{array}$ \\
\hline LEVERAGE & $\begin{array}{l}0.020^{* * *} \\
(6.70)\end{array}$ & $\begin{array}{l}0.020^{* * *} \\
(6.69)\end{array}$ & $\begin{array}{l}0.020^{* * *} \\
(6.77)\end{array}$ & $\begin{array}{l}0.020^{* * *} \\
(6.75)\end{array}$ & $\begin{array}{l}0.020^{* * *} \\
(6.77)\end{array}$ \\
\hline ROE & $\begin{array}{l}-0.001 \\
(-0.07)\end{array}$ & $\begin{array}{l}-0.002 \\
(-0.11)\end{array}$ & $\begin{array}{l}-0.003 \\
(-0.15)\end{array}$ & $\begin{array}{l}0.001 \\
(0.03)\end{array}$ & $\begin{array}{l}-0.003 \\
(-0.16)\end{array}$ \\
\hline GROWTHSALES & $\begin{array}{l}-0.002 \\
(-1.06)\end{array}$ & $\begin{array}{l}-0.002 \\
(-1.10)\end{array}$ & $\begin{array}{l}-0.002 \\
(-0.85)\end{array}$ & $\begin{array}{l}-0.003 \\
(-1.19)\end{array}$ & $\begin{array}{l}-0.002 \\
(-0.85)\end{array}$ \\
\hline TOPSHARE & $\begin{array}{l}-0.031 \\
(-1.23)\end{array}$ & $\begin{array}{l}-0.028 \\
(-1.11)\end{array}$ & $\begin{array}{l}-0.027 \\
(-1.06)\end{array}$ & $\begin{array}{l}-0.026 \\
(-1.03)\end{array}$ & $\begin{array}{l}-0.027 \\
(-1.07)\end{array}$ \\
\hline FIRMAGE & $\begin{array}{l}0.002^{* *} \\
(2.46)\end{array}$ & $\begin{array}{l}0.002^{* *} \\
(2.54)\end{array}$ & $\begin{array}{l}0.002^{\text {** }} \\
(2.35)\end{array}$ & $\begin{array}{l}0.002^{* *} \\
(2.47)\end{array}$ & $\begin{array}{l}0.002^{* *} \\
(2.36)\end{array}$ \\
\hline CEODUALTIY & $\begin{array}{l}0.017^{* *} \\
(2.13)\end{array}$ & $\begin{array}{l}0.017^{* *} \\
(2.11)\end{array}$ & $\begin{array}{l}0.013^{*} \\
(1.68)\end{array}$ & $\begin{array}{l}0.016^{* *} \\
(2.04)\end{array}$ & $\begin{array}{l}0.013^{*} \\
(1.69)\end{array}$ \\
\hline BOARDSIZE & $\begin{array}{l}-0.006^{* * *} \\
(-3.03)\end{array}$ & $\begin{array}{l}-0.006^{* * * *} \\
(-3.05)\end{array}$ & $\begin{array}{l}-0.006^{* * *} \\
(-2.87)\end{array}$ & $\begin{array}{l}-0.006^{* * *} \\
(-3.06)\end{array}$ & $\begin{array}{l}-0.006^{\text {*** }} \\
(-2.88)\end{array}$ \\
\hline MINDEX & $\begin{array}{c}-0.001 \\
(-0.64)\end{array}$ & $\begin{array}{c}-0.001 \\
(-0.53)\end{array}$ & $\begin{array}{c}-0.001 \\
(-0.63)\end{array}$ & $\begin{array}{c}0.003 \\
(1.40)\end{array}$ & $\begin{array}{l}-0.001 \\
(-0.42)\end{array}$ \\
\hline FAMILYCHAIR & & $\begin{array}{c}0.007 \\
(0.82)\end{array}$ & $\begin{array}{c}-0.012 \\
(-1.53)\end{array}$ & $\begin{array}{c}0.004 \\
(0.51)\end{array}$ & $\begin{array}{l}-0.012 \\
(-1.54)\end{array}$ \\
\hline NFG*FAMINV & & $\begin{array}{l}0.018^{* *} \\
(1.97)\end{array}$ & & $\begin{array}{l}0.107^{* * *} \\
(3.80)\end{array}$ & \\
\hline NFC*FAMINV*MINDEX & & & & $\begin{array}{l}-0.010^{* * *} \\
(-3.34)\end{array}$ & \\
\hline NFG*INTERLOCK & & & $\begin{array}{l}-0.024^{* * *} \\
(-2.59)\end{array}$ & & $\begin{array}{c}-0.017 \\
(-0.60)\end{array}$ \\
\hline NFC*INTERLOCK*MINDEX & & & & & $\begin{array}{l}-0.001 \\
(-0.22)\end{array}$ \\
\hline Constant & $\begin{array}{l}0.126^{*} \\
(1.81)\end{array}$ & $\begin{array}{l}0.125^{*} \\
(1.80)\end{array}$ & $\begin{array}{l}0.122^{*} \\
(1.76)\end{array}$ & $\begin{array}{c}0.085 \\
(1.21)\end{array}$ & $\begin{array}{l}0.120^{*} \\
(1.72)\end{array}$ \\
\hline $\mathcal{N}$ & 1785 & 1785 & 1785 & 1785 & 1785 \\
\hline$R^{2}$ & 0.117 & 0.119 & 0.120 & 0.124 & 0.120 \\
\hline adj. $R^{2}$ & 0.099 & 0.100 & 0.102 & 0.106 & 0.101 \\
\hline $\mathrm{F}$ & 6.796 & 6.536 & 6.625 & 6.699 & 6.444 \\
\hline
\end{tabular}

Notes: $t$ statistics in parentheses, ${ }^{*} p<0.10,{ }^{* *} p<0.05,{ }^{* * *} p<0.01$.

presence leads to $1.8 \%$ higher volume of RPLG and an interlocking non-family chairman leads to $2.4 \%$ lower volume of RPLG. Considering that in our sample the average of RPLG is $3.22 \%$ and the average total assets is 1.33 billion Yuan, the effect of a non-family chairman (with family influence) can be translated into a 56\% average increase of RPLG in percentage or a 23.94-million Yuan increase in loan guarantees to related parties; the effect of an interlocking non-family chairman can 
be translated into a 74\% average decrease of RPLG in percentage or a 31.92-million Yuan decrease in loan guarantees to related parties.

\section{Test Results for Hypotheses 4 and 5}

In Models 4 and 5 of Table 3, we examine how the effect of family governance structure on loan guarantees varies with regional institutional development. To save space, we present only the results of testing the moderating influence of institutional development on $\mathrm{H} 2$ and $\mathrm{H} 3 \mathrm{~b}$, which are not rejected in the previous empirical tests.

In Model 4 of Table 3, we find that the coefficient of NFG*FAMINV*MINDEX is -0.01 and significant at the $1 \%$ level, lending strong support for $\mathrm{H} 4$. However, the coefficient of $\mathrm{NFC}^{*}$ INTERLOCK* MINDEX in Model 5 is -0.001 and statistically insignificant. Thus, H5 is not supported.

\section{Results of Control Variables}

Although the estimates of control variables are not our main focus, the effects of our control variables will be dealt with briefly. The DIVERGENCE coefficients for all five models are positive and significant. A high value for DIVERGENCE indicates large disparity between control and cash flow rights. Such disparity is an incentive for expropriation, which may happen by means of loan guarantees to related parties. LEVERAGE also appears positive and highly significant in all regressions. The effects of FIRMAGE and CEODUALITY are also positive and significant across most models implying that older LAFs and LAFs with less efficient governance tend to give more loan guarantees to related parties. In contrast, the BOARDSIZE coefficients are negative and significant in most regressions as expected. All external loan guarantees must be approved by the board or shareholders' meeting; the results thus indicate that the controlling families have more trouble controlling larger boards. Lastly, in our results, measures for pyramidal layer, regional institutional development, firm size, profitability, growth opportunities and largest shareholdings are generally insignificant.

\section{Robustness Tests}

To show the robustness of the findings of our previous tests, we tested $\mathrm{H} 2$ and $\mathrm{H} 3$ with subsamples. The first subsample consisted of sample firms with FAMILYCHAIR $=0$ (or NFG $=1)$ to test the direct effects of FAMINV and INTERLOCK separately. The second subsample consisted of sample firms with FAMINV $=1$ and was used to test the effect of NFC. The third subsample consisted of sample firms with INTERLOCK $=1$ and was used to test the effect of NFC. The results are not qualitatively different from the full sample tests.

In the main analysis, INTERLOCK was defined as 1 if a listed firm chairman holds the position of divisional manager level or higher in the apex firm. To test 
whether our results are sensitive to this definition, we narrowed our definition so that INTERLOCK was defined as 1 if a listed firm chairman holds a position at the vice general manager level or higher in the apex firm. Using the new definition of interlocking chairman, we find results very similar to our previous findings. To avoid bias introduced by outliers, we modify the winsorizing of Guarantee, ROE and Leverage from $1 \%$ and $99 \%$ to $2 \%$ and $98 \%$ and replace ROE by ROA in the regressions. We also re-estimated our main models excluding variables insignificant in our estimates, for example, LNASSETS, GROWTHSALES and TOPSHARE. These robustness checks do not alter our main findings. Finally, to correct the potential biases introduced by firm-year pooled OLS regressions, we re-estimate the models in our main tables using panel regressions with fixed effect. Whether adjusted for heteroskedasticity or not, we generally find quite similar results with OLS regressions showing negative effects of vertical interlock and positive effects of family influence on loan guarantees. ${ }^{[2]}$

\section{DISGUSSION}

We based our theoretical framework on an assumption of heterogeneity of family involvement, which means that family involvement, by itself, cannot be assumed to lead to expropriation by default. The fact that we find no support for $\mathrm{H} 1$ reflects this. Only family involvement in listed firms through roles other than chairmanship leads to increases in RPLG. Our primary explanation for why we find support for $\mathrm{H} 2$ but not $\mathrm{H} 1$ comes in two versions. The first is that if family owners seek to use loan guarantees but know that this can create conflicts with minority shareholders, they will shun high profile involvement in a listed firm they want to use as guarantor. However, they will nevertheless require family presence as a lever to bring about the issuing of loan guarantees. The other explanation reverses the causal flow. If there is a strong family visibility in the listed firms through a family chairman, then family owners will have weaker incentives to use loan guarantees as this again can create conflicts, in the case of which a visible controlling role will cast an unwanted light on the family. If on the other hand there is a less visible family presence, then the incentive is stronger as the family still has the means but now without the risk of too much exposure. The appointment of both family and interlocking managers are decisions that rest with the family owners, but as mentioned in the introduction, we cannot analytically determine whether family presence is a signal of intent to expropriate or whether it is a control structure that may help facilitate expropriation if and when the wish to do so arises. We suspect, however, that both explanations may apply. We note that managerial appointments often have longevity but we believe that the wish to expropriate is occasional rather than constant (Fan, Wei, \& $\mathrm{Xu}, 2001: 210)$. In addition to this, another reason for why we found no support for $\mathrm{H} 1$ could be that some family chairmen are founders of, and have a socio-emotional attachment to, the LAFs, which would reduce likelihood of such chairmen inflicting 
financial harm on the LAF. Thus, family chairmen constitute a diverse group with different motives and actions.

As for interlocks, we believe that interlocking non-family chairmen discourage issuance of loan guarantees because interlocking chairs through the interlock have clear connections to the controlling family, which may create unwanted visibility and accountability. Moreover, and not less importantly, these non-family chairs may have allegiances to the listed firm and its non-family shareholders, and can now use the interlocking position in the apex firm to promote the interest of those shareholders. These two factors are strong enough to counteract family presence. We cannot ascertain which of the two factors carries more weight. In combination these two factors clearly outweigh any gain of family control over the LAF through interlocks, which formed the basis for (the rejected) H3a.

Our results lend credence to claims that family involvement is far from one uniform category with uniform goals or behaviour (Chua et al., 2012). We have found radically different behaviour concerning RPLG when comparing family chair to family presence. This supports claims that different configurations of family involvement can lead to different family firm behaviour (Tagiuri \& Davis, 1996). As for goals and outcomes we see both family involvement and interlocking ties as governance configurations created by family owners to ensure control in a general sense. Put differently, such control can be created for many different purposes, economic or non-economic, family oriented or focused on the firm and its stakeholders (Kotlar \& De Massis 2013). Research on family firms has shown that the causal relationship between family ability and willingness to pursue specific family oriented goals is not necessarily direct (Chrisman, Chua, De Massis, Frattini, \& Wright 2014; Chrisman et al., 2012; De Massis, Kotlar, Chua, \& Chrisman, 2014). Reflecting this, our explanations do not assume that family owners by definition pursue issuance of loan guarantees or otherwise attempt to expropriate minority shareholders. However, the actions taken by the family owners in terms of types of involvement and governance generally will have an effect on the extent of any later loan guarantees issuance.

A couple of examples may explicate the two points made so far. If the listed firm is seen as integral to the business group, the family owner would put great emphasis on having control over, and be able to coordinate with, that listed firm. This might be done by installing the family owner, or a family relative who also has a managerial role in the apex firm, as chair of the listed firm, thus creating a family interlock. The control gained by such a family interlock would however be so visible that it may become less desirable to issue loan guarantees to other group firms. If no suitable relative can be found, but control and coordination remains a priority, an outside chairman of the listed firm could be given an interlocking position in the apex firm. This would ensure control and coordination but now of a type that would decisively not help facilitate use of loan guarantees, both because of the loyalties of the interlocking non-family manager to the LAF and because of unwanted visibility. Yet, if circumstances dictate it the family owner might accept 
that constraint. If the listed firm on the other hand is not a priority - or perhaps is seen as a vehicle for financing other branches of the family-controlled group - then an interlock would not be so essential (and nor would a family chair). Nevertheless, to be able to influence the board of such a listed firm, the family owner may appoint family members to the board. Indeed, the family owner may in such cases appoint family board members with the specific goal of using loan guarantees. To repeat, decisions to create specific control structures such as interlocking and/or family ties can be rooted in goals, which may go beyond using loan guarantees to extract value from the listed firm. But importantly, any subsequent attempts or wishes to use loan guarantees would be constrained or enabled by these chosen control structures.

Our findings concerning the moderating effects of institutional development on family presence show that stronger institutions reduce the impact of family presence on RPLG. Thus, the support for $\mathrm{H} 4$ indicates a developmental trajectory where P-P agency problems are reduced as institutions develop. Equally important, the results paint a picture of disparities in institutional development across China's provinces disparities that have consequences. That we find no corresponding support for $\mathrm{H} 5$ may be taken to mean that institutional regulation still is not sufficient enough, even in the most developed provinces, to render the protection afforded by interlocks redundant.

The incremental increases in R-square between our models (Table 3) are generally small. The small increases in R-square have two reasons. First, several of the variables added to the models are dummy variables, which by default do not increase much variation. Second, FAMILYCHAIR appears insignificant in all models. These two reasons also lead to the decrease of F-statistics when comparing Model 1 with subsequent models. For example, the F-value in Model 2 is 6.536, smaller than the F-value of 6.796 in Model 1. The F-test is a joint test of all the coefficients in a model. When we add insignificant variables, for instance FAMILYCHAIR, to the models, they actually hurt the models' fit with the data. Similarly, we observe a decline in the F-statistics of Model 5 from that of Model 3 after we add an insignificant coefficient. To illustrate this, if we exclude FAMILYCHAIR from Models 2-5, the F-statistics increase stepwise from Model 1 to 4 with model 4 reaching an F-value of 6.881 (adding a new insignificant variable in Model 5 however causes the F-value of that model to be lower than Model 4's).

\section{Limitations}

The decrease of F-values in-between our reported models is a limitation of our study, which we discussed previously. Our lack of concern with the specific causal flow between intentions (willingness) to expropriate, family and interlocking ties (ability), and actual volume of loan guarantees may also be seen as a limitation. Nevertheless our results show a clear and important association. Organizational theory has long proposed that clear-cut distinctions between agency (family owners creating specific ties because they want to use loan guarantees) and structure (family owners being 
able or constrained in their attempts to use loan guarantees by specific ties) is a fallacy (Powell \& Dimaggio 1991). Reality is often in-between. Another objection to our study could be that loan guarantees ought to be seen simply as a way of mitigating financial constraints rather than a tool for expropriation. But if financial constraint is the main explanation for related-party loan guarantee, we would expect that institutional development, which should alleviate financial constraints, would reduce the use of such loan guarantees. This is not the case. If, however, low institutional development creates an incentive for using loan guarantees for the private benefits of family owners, then we should not expect any main effect of institutional development, but we would indeed expect family presence and institutional development to interact. This is consistent with our results.

We have here focused on an issue that we argue relates to P-P agency problems. But family involvement may reduce P-A agency problems, and that benefit may exceed the costs associated with loan guarantees (or P-P agency costs in total). Our results therefore do not contradict results showing positive effects of family involvement on firm value (Cai et al., 2012) or family strategic control, i.e., having a family chairman (Luo \& Chung, 2013). Our results suggest that outside chairs can best reduce expropriation by controlling apex firms if there is no family influence and they have interlocking positions in the apex firms. This complements Luo and Chung (2013).

Our results raise the question as to whether they apply to family-owned business pyramids in other countries. There are a number of reasons why the results may not apply everywhere. First, regulation in other countries might give owners other options than loan guarantees for expropriation (or remove loan guarantees as an option). Second, our results concerning the moderating impact of institutional development and also the direct effect of board size indicate that more institutionally developed countries most likely do not exhibit the same effects of family presence analysed here. Third, regulation in other countries may prohibit the use of vertical interlocks of the type described here (see also below). Fourth, we speculated above that neither family nor interlocking ties are necessarily created with only the specific intent to facilitate loan guarantees. They may also be created to fulfil other purposes of control and coordination. Non-family interlocking ties, however, create obstacles for using loan guarantees if the need arises. Therefore, family owners may prefer family interlocks but may, if there is a lack of suitable family candidates, opt for a non-family interlock. Interestingly, the one-child policy is a China-specific factor reducing the pool of family candidates in Chinese family-owned groups. As a result, we may see more non-family interlock arrangements rather than family chair interlock ones. Fifth, we know from the literature that horizontally interlocking directorates (dual board membership) is common in many countries. However, there is virtually no information about vertical interlocks and/or interlocks other than through board directors in other countries so we cannot ascertain how common they are outside China, and whether they are of the same type. Also, as mentioned earlier the degree of responsibility bestowed on Chinese board chairs is relatively 
unique. And if (non-family) interlocks are alternatives to family involvement (even though they come at a price to the family owners when it comes to expropriation) we do not know whether this applies outside of China either. Obviously, these knowledge gaps point to avenues of future research.

\section{GONGLUSION}

We found clear evidence that the use of loan guarantees to related parties in family-owned business groups varies in accordance with family and interlocking managerial ties. Generally, family involvement is not associated with greater use of loan guarantees to related parties, but our results just as clearly show that different types of family involvement have different implications. Our results add to a developing body of literature that distinguishes between different types of family involvement (De Massis et al., 2014; Gedajlovic et al., 2012; Lubatkin et al., 2007), stressing that family owners take different paths with different outcomes in terms of agency problems. The causes of such differences are not identified here, but it is documented that family involvement in Chinese family-owned business groups is not a homogenous phenomenon. Also we have shown that family ties in Chinese firms create bonds of loyalty, which potentially may lead to P-P agency problems. These problems do, however, seem to be reduced by institutional development.

\section{SUPPLEMENTARY MATERIAL}

To view supplementary material for this article, please visit http://dx.doi.org/ $10.1017 /$ mor.2015.22

\section{NOTES}

We wish to thank MOR and Zhejiang University for arranging a special issue workshop on Chinese Family Business in Hangzhou in October 2013. We wish to thank all participants at the workshop for the constructive discussions. We are particularly indebted to Jess Chua for his editorial input and help in developing our paper during two subsequent rounds of revision. We also wish to thank Anne Tsui and the anonymous referees. We wish to acknowledge financial support from the Liberal Arts Research and Innovation Plan of Shanghai Jiao Tong University; Sino-Danish Center for Education and Research; Aarhus Research Foundation; Science Foundation of Ministry of Education of China (Grant No. 12YJA630092); and National Natural Science Foundation of China (Grants No. 71262019 and 71462031).

[1] In what follows we will use 'family involvement' as a general term denoting controlling family member(s) serving as director(s), manager(s) or supervisor(s) in an affiliate. We as mentioned above distinguish between two types of involvement, one where the board chair is a family member (which we will refer to simply as 'family chair'), and one where involvement is in the form of family directors (other than chairman), supervisors, or senior managers. We will refer to this latter type as 'family presence.'

[2] Due to space limitations, the robustness test results are not presented. They are available from the authors upon request. 


\section{REFERENCES}

Berkman, H., Cole, R. A., \& Fu, L. J. 2009. Expropriation through loan guarantees to related parties: Evidence from China. Journal of Banking and Finance, 33(1): 141-156.

Bhaumik, S. K., \& Gregoriou, A. 2010. 'Family' ownership, tunnelling and earnings management: A review of the literature. Journal of Economic Surveys, 24(4): 705-730.

Bourdieu, P. 1986. The forms of capital. In J. G. Richardson (ed.), Handbook of theory and research for the sociology of education: 241-258. New York: Greenwood Press.

Cai, D., Luo, J.-H., \& Wan, D.-F. 2012. Family CEOs: Do they benefit firm performance in China? Asia Pacific Journal of Management, 29(4): 923-947.

Carney, M., Gedajlovic, E. R., Heugens, P. P. M. R., Essen, M. V., \& Oosterhout, J. H. V. 2011. Business groups affiliation, performance, context and strategy: A meta analysis. Academy of Management Journal, 54(3): 437-460.

Chakrabarty, S. 2009. The influence of national culture and institutional voids on family ownership of large firms: A country level empirical study.Journal of International Management, 15(1): $32-45$.

Cheung, Y.-L., Rau, P. R., \& Stouraitis, A. 2006. Tunneling, propping, and expropriation: evidence from connected party transactions in Hong Kong. Journal of Financial Economics, 82(2): 343-386.

Chrisman, J.J., Chua, J. H., \& Sharma, P. 2005. Trends and directions in the development of a strategic management theory of the family firm. Entrepreneurship Theory and Practice, 29(5): 555-576.

Chrisman, J. J., Chua, J. H., Pearson, A. W., \& Barnett, T. 2012. Family involvement, family influence, and family-centered non-economic goals in small firms. Entrepreneurship Theory and Practice, 36(2): 267-293.

Chrisman, J. J., Chua, J. H., De Massis, A., Frattini, F., \& Wright, M. 2014. The ability and willingness paradox in family firm innovation. Journal of Product Innovation Management, Forthcoming. Published online July 2014.

Chu, W. Y. 2011. Family ownership and firm performance: Influence of family management, family control, and firm size. Asia Pacific Journal of Management, 28(4): 833851.

Chua, J. H., Chrisman, J. J., Steier, L. P., \& Rau, S. B. 2012. Sources of heterogeneity in family firms: An introduction. Entrepreneurship Theory \& Practice, 36(6): 1103-1113.

Chung, H. M., \& Chan, S. T. 2012. Ownership structure, family leadership, and performance of affiliate firms in large family business groups. Asia Pacific Journal of Management, 29(2): 303-329.

Claessens, S., Djankov, S., \& Lang, L. H. P. 2000. The separation of ownership and control in East Asian corporations. Journal of Financial Economics, 58 (1-2): 81-112.

De Massis, A., Kotlar, J., Chua, J. H., \& Chrisman, J. J. 2014. Ability and willingness as sufficiency conditions for family-oriented particularistic behavior: Implications for theory and empirical studies. Journal of Small Business Management, 52(2): 344-364.

Fama, E. F., \& Jensen, M. C. 1983. Agency problems and residual claims. Journal of Law and Economics, 26(2): 327-349.

Fan, J. P. H., Wei, J. K. C., \& Xu, X. 2011. Corporate finance and governance in emerging markets: A selective review and an agenda for future research. Journal of Corporate Finance, 17(2): 207-214.

Gedajlovic, E., Carney, M., Chrisman, J.J., \& Kellermanns, F. W. 2012. The adolescence of family firm research: Taking stock and planning for the future. Journal of Management, 38(4): 1010-1037.

Giddens, A. 1984. The constitution of society. Cambridge: Polity Press.

Haunschild, P. R., \& Beckman, C. M. 1998. When do interlocks matter? Alternate sources of information and interlock influence. Administrative Science Quarterly, 43(4): 815844.

He, J., Mao, X., Rui, O. M., \& Zha, X. 2013. Business groups in China. Journal of Corporate Finance, 22: 166-192.

Jiang, G., Lee, C., \& Yue, H. 2010. Tunneling through intercorporate loans: The China experience. Journal of Financial Economics, 98(1): 1-20.

Jiang, Y., \& Peng, M. K. W. 2011. Are family ownership and control in large firms good, bad, or irrelevant? Asia Pacific Journal of Management, 28(1): 15-39. 
Keister, L. A. 1998. Engineering growth: Business group structure and firm performance in China's transition economy. American Journal of Sociology, 104(2): 404-440.

Khanna, T., \& Yafeh, Y. 2005. Business groups and risk sharing around the world. Journal of Business, 78(1): 301-340.

Khanna, T., \& Yafeh, Y. 2007. Business groups in emerging markets: Paragons or parasites? Journal of Economic Literature, 45(2): 331-372.

Khanna, T., \& Thomas, C. 2009. Synchronicity and firm interlocks in an emerging market.Journal of Financial Economics, 92(2): 182-204.

Kim, Y., \& Gao, F. Y. 2010. An empirical study of human resource management practices in family firms in China. International Journal of Human Resource Management, 21(12): 20952119.

Kotlar, J., \& De Massis, A. 2013. Goal setting in family firms: Goal diversity, social interactions, and collective commitment to family-centered goals. Entrepreneurship Theory and Practice, 37(6): 1263-1288.

La Porta, R., Lopez-de-Silanes, F., \& Shleifer, A. 1999. Corporate ownership around the world. Journal of Finance, 54(2): 471-517.

Le Breton-Miller, I., \& Miller, D. 2009. Agency vs. stewardship in public family firms: A social embeddedness reconciliation. Entrepreneurship Theory \& Practice, 37(6): 1169-1 191.

Liao, G., Chen, X., Jing, X., \& Sun, J. 2009. Policy burdens, firm performance, and management turnover. China Economic Revieze, 20(1): 15-28.

Lincoln, J. R., Gerlach, M. L., \& Takahashi, P. 1992. Keiretsu networks in the Japanese economy A dyad analysis of intercorporate ties. American Sociological Revieze, 57(5): 561-585.

Lu, Y., \& Tao, Z. 2009. Contract enforcement and family control of business: Evidence from China. Journal of Comparative Economics, 37(4): 597-609.

Lubatkin, M. H., Schulze, W. S., Ling, Y., \& Dino, R. N. 2005. The effects of parental altruism on the governance of family-managed firms. Journal of Organizational Behavior, 26(3): 313 330 .

Lubatkin, M. H., Ling, Y., \& Schulze, W. S. 2007. An organizational justice-based view of selfcontrol and agency costs in family firms. Journal of Management Studies, 44(6): 955971.

Luo, X., \& Chung, C.-N. 2005. Keeping it all in the family: The role of particularistic relationships in business group performance during institutional transition. Administrative Science Quarterly, 50(3): 404-439.

Luo, X. R., \& Chung, C.-N. 2013. Filling or abusing the institutional void? Ownership and management control of public family business in an emerging market. Organization Science, 24(2): 591-613.

Masulis, R. W., Pham, P. K., \& Zein, J. 2011. Family business groups around the world: Financing advantages, control motivations, and organizational choices. Revieze of Financial Studies, 24(11): 3556-3600.

Miller, D., Lee, J., Chang, S., \& Le Breton-Miller, I. 2009. Filling the institutional void: The social behavior and performance of family vs. non-family technology firms in emerging markets. Journal of International Business Studies, 40(5): 802-817.

Peng, M. W. 2004. Outside directors and firm performance during institutional transitions. Strategic Management Journal, 25(5): 453-471.

Peng, M. W., \& Jiang, Y. 2010. Institutions behind family ownership and control in large firms. Journal of Management Studies, 47(2): 253-273.

Powell, W. W., \& Dimaggio, P. J. 1991. The new institutionalism in organizational analysis. Chicago: Chicago University Press.

Rocha,J. M. 2012. Business groups as hierarchical clique structures: A conceptual and methodological discussion as it applies to the Mexican experience. British Journal of Management, 23(3): 291-306.

Sirmon, D. G, Arregle, J. L., Hitt, M. A., \& Webb, J. W. 2008. The role of family influence in firms' strategic responses to threat of imitation. Entrepreneurship Theory \& Practice, 32(6): 979998.

Sharma, P., \& Chua, J. 2013. Asian family enterprises and family business research. Asia Pacific Journal of Management, 30(3): 641-656.

Singal, M., \& Singal, V. 2011. Concentrated ownership and firm performance: does family control matter? Strategic Entrepreneurship Journal, 5(4): 373-396.

Tagiuri, R., \& Davis, J. 1996. Bivalent attributes of the family firm. Family Business Revieze, 9(2): $199-208$. 
Xu, L., Zhu, T., \& Lin, Y. M. 2005. Politician control, agency problems and ownership reform Evidence from China. Economics of Transition, 13(1): 1-24.

Young, M. N., Peng, M. W., Ahlstrom, D., Bruton, G. D., \& Jiang, Y. 2008. Corporate governance in emerging economies: A review of the principal-principal perspective.Journal of Management Studies, 45(1): 196-220.

Zhou, J., Tam, O. K., \& Yu, P. 2013. An investigation of the role of family ownership, control and management in listed Chinese family firms. Asian Business \& Management, 12(2): 197-225.

Xin Chen (xinch@sjtu.edu.cn) has been an Associate Professor in Dept. of Accounting, Shanghai Jiao Tong University since 2006. He received a Ph.D. from University of Minnesota and taught in People's University of China and Aarhus University in Denmark. He also visited Massachusetts Institute of Technology as a faculty fellow. He mainly conducts empirical research in corporate finance, accounting and capital markets, institutional investors and trading strategies based on market manipulation.

Jakob Arnoldi (jaar@badm.au.dk) is Professor at Department of Management, School of Business and Social Sciences, Aarhus University. He is also affiliated with the Sino-Danish Center for Education and Research. He is primarily doing research on Chinese firms, risk and uncertainty, and innovations in the financial sector.

Chaohong Na (chna@ynufe.edu.cn) is an Associate Professor in the Business School, Yunnan University of Finance and Economic. He received a Ph.D. from Jinan University. He has visited Aarhus University, Chinese University of Hong Kong, and China Europe International Business School. He mainly conducts empirical research in business group governance, corporate finance and capital markets.

Manuscript received: February 28, 2013

Final version accepted: April 16, 2015

Accepted by: Jess Chua 